\title{
UDC 001.9
}

\section{THE DISCLOSURE OF UKRAINIAN SCIENTISTS' RESEARCH RESULTS IN ACADEMIC JOURNALS: PROBLEMS AND PROSPECTS}

\author{
S. B. Fiialka \\ Institute of Publishing and Printing of the National Technical University of Ukraine \\ «Igor Sikorsky Kyiv Polytechnic Institute», \\ 37, Prospect Peremogy, Kyiv, 03056, Ukraine
}

A survey of Ukrainian scholars on the Ukrainian academic journals' level and their experience in interacting with editiorial boards of academic journals, which are indexed in Web of Science and Scopus, has been conducted in the Ukrainian Scientists Worldwide group on Facebook by filling out the Google form. In total, 296 scientists from different fields took part in the survey. The questionnaire allowed to gather various, often diametrically opposed, thoughts about why scientists publish (do not publish) their articles in journals included to Web of Science or Scopus; what the main reviewers' comments on their articles were; for what reason the Ministry of Education and Science requires scholars to have articles in academic journals included to international databases; who is financing the publication fee; how important the knowledge of foreign languages for the preparation of scientific papers is; how the authors interact with the editors during the editorial and publishing process; what the main researchers' motivation to write scientific articles is; how scholars evaluate the practice, when people who are not actually co-authors of the articles are added as co-authors by agreement; how the authors refer to plagiarism and on the basis of which criteria researchers select a journal for publication.

The results of the survey have shown contradictory tendencies of Ukrainian researchers'publication activity. On the one hand, it is a desire to reach the international level, to gain recognition, an attempt to adhere to high standards, to improve own skills. On the other hand, pursuit of quantitative indicators, low motivation, violations of academic integrity, low level of proficiency in the languages of international scientific communication. In pursuit of quantity there is no place for scientific values, such as novelty, uniqueness, informativeness.

Keywords: academic journal, academic integrity, plagiarism, review, peer-reviewed journal, editing, editorial board.

\section{Introduction}

Academic journals are a long-standing, proven and popular worldwide tool for fixing and disseminating information created by scientists. Such editions generalize the results of theoretical or experimental studies conducted by individual scientists or groups of scientists; support further scientific research and cooperation; stimulate debats on current academic issues; provide scholars and practitioners with access to brand-new 
scientific achivements. At the same time, the number of pseudo-scientific publications, which are disseminated by low-quality academic journals, is growing all over the world. Alternative language for such journals includes "dubious," "low credibility," "deceptive," "dodgy", "scholarly bad faith." The terms "fake journals," "sham journals," and "pseudojournals" are also widely used.

A complete list of all professional editions in Ukraine (by branches of knowledge) contains 1546 titles of printed journals and collections of scientific works and 90 electronic publications [1]. At the same time, the citation and recognition of scientific results by the international community are at an extremely low level. Recent proliferation of dodgy journals attracting inexperienced or desperate authors is a response to their exaggerated career advancement and promotion plans, which are grounded on quantity but not quality. The pursuit of the number of publications generates plagiarism, falsification of the scientific research results, and hence the production of a growing number of dubious papers that nobody will ever read. Only 98 Ukrainian scientific journals are part of the world-renowned community of Scopus and Web of Science databases, known for close checking before adding journals [2]. Since in the career of every Ukrainian scholar there are mandatory barriers to meet the requirements of the Ministry of Education and Science of Ukraine on the number of publications, the editorial offices of dubious journals send up letters with suggestions to submit the papers. In addition, there are many "firms" offering authors the "help" with writing and publishing an articles in the journals belonging to Scopus or Web of Science. Such practice not only damages the scientists' reputation, but also clogs the academic information space and undermines the credibility of Ukrainian science.

\section{Literature review}

The role of the academic journal is to serve for both sides of the market: to deliver novel, relevant, quality-assured articles to the reader; and to bring a large, specific, relevant audience of readers to the author [3]. C. Bergstrom and T. Bergstrom classified academic journals and publishers into two groups: journals controlled by "non-profit" professional societies, and those controlled by profit-motivated commercial publishers [4]. Respectively, he mode of publication in a journal is broadly categorized into two models: reader pays model and author-side pays model. Reader pays is the traditional model in which the publishers obtain their revenues from subscription fees charged to libraries and individual users. Author-side pays is a new model which has developed due to the combination of advancement in Internet and open access. In this model, the publishers obtain their revenues through article processing charges from the authors who pay to make their articles available to everybody [5].

Unfortunately, there are a lot of publishers in the scholarly publishing business who collect article processing charges and provide rapid publishing without a proper peerreview process. J. Beall (a library scientist at the University of Colorado, Denver, USA) coined the term "predatory publishers" to describe such publishers [6]. To separate this sort of predatory journals from peer-reviewed journals, J. Beall defined a list of criteria and suggested predatory publishers and journals can usually be characterized by their constant submission of spam e-mails to the researchers in order to solicit new paper 
submission. This list is rather long with 48 criteria which directly or indirectly indicate whether the publisher and individual journal is predatory [7]. With this J. Beall does not support a regulatory body to oversee scholarly publishers; instead, he believes that the best defence against unethical publishers is education, and "the ability to recognise publishing fraud" through scientific literacy [6].

J. Xia, J. Harmon, K. Connolly, and others collected and analyzed the publication record, citation count, and geographic location of authors from the various groups of journals. Statistical analyses verify that each group of journals has a distinct author population. Those who publish in "predatory" journals are, for the most part, young and inexperienced researchers from developing countries [8].

But it's clear that many academics know exactly what they're getting into, which explains why deceptive journals have proliferated inspite of criticism. G. Kolata says that "the relationship is less predator and prey, than a new and ugly symbiosis" [9].

P. Thrower revealed the main signs of low quality academic article. These include the following: the article contains plagiarism; the article is not completed; the paper contains obsolete publications in the list of references; the article does not comply with the requirements of the Rules for the authors of the academic journal; does not correspond to the aim and scope of the journal, does not contain scientific novelty; one-sided coverage of scientific discourse (some significant studies are taken into account, but others are ignored); research methods do not correspond to commonly recognized parameters and procedures; conclusions are not substantiated in the text of the article; the text of the article was created on the basis of other works of the author; the article is incomprehensible; the article is uninteresting and can not be interesting for the readers of the journal [10].

In Ukraine, the first steps have been taken recently to improve academic journals. In particular, in accordance to Order of the Ministry of Education and Science of Ukraine dated January 15, 2018 No. 32 on Approval of the Procedure for the Formation of the List of Scientific Professional Journals of Ukraine were formulated the criteria for the list of scientific professional journals of Ukraine.

These journals were divided into 3 categories. Category $\mathrm{C}$ includes the journalas that meet the minimum requirements. This is a certificate of state registration; ISSN; DOI; the web site of the journal with the Ukrainian and English interfaces or the webpage of the journal on the founder's web site with the information on the policy of the journal, the list of members of the editorial board, the information about the review process and the adherence to ethics, the recommendations on preparing publications and submitting procedure; an annotation in English of at least 1800 characters per article. The requirement for the editions of this group is also placement on the platform "Scientific Periodicals of Ukraine" in the National Library of Ukraine named after V. Vernadsky National Academy of Sciences of Ukraine and the National Repository of Academic Texts.

Category B includes the journals that meet the specified requirements for the publications of Group C, as well as requirements such as ensuring a qualitative independent review of materials submitted for publication by scientists conducting research in a specialty and having for the last three years not less than one publication in journals 
included to the List, or to foreign publications included to Web of Science Core Collection and / or Scopus, or have monographs or sections of monographs issued by international publishing houses classified as "A," "B" or " $C$ " by classification Research School for Socio-Economic and Natural Sciences of the Environment (SENSE). The editorial board must include at least seven scientists with a degree in one of the specialties corresponding to the scientific profile of the journal. Each of these specialists, including the editor-in-chief, must have at least three publications in the last five years or at least seven publications (articles, monographs, sections of monographs corresponding to the scientific profile of the publication) during the last fifteen years, in that including at least one in the last three years, published in at least two different editions included to Web of Science Core Collection and / or Scopus, or have monographs or sections of monographs issued by international publishers belonging to the categories "A," "B" or "C" by classification of Research School for Socio-Economic and Natural Sciences of the Environment (SENSE). In addition, the editorial board should include not less than three scholars working at the main place of work in Ukrainian academic institutions or higher education institutions, and at least one scientist working at the main place of employment in a foreign scientific institution or institution of higher education. To include a scientist in the editorial board, his written consent is required. In addition, the scholar may be a member of not more than three editorial boards of editions included in the List.

The highest category A includes Ukrainian journals that are included to Scopus and/or Web of Science Core Collection. In accordance to the order the journals of the category " $C$ ", which by 2020 does not receive the right to assign category "A" or category "B," is excluded from the List without the right to renew. Reasons for excluding the publication from the List may also be: violation of the principles of academic integrity, provided by the laws of Ukraine; systematic publications the materials that do not include new scientific results, and at the same time do not contain information that they are observational or scientific-methodical [11].

The purpose of the article is:to identify the motives of Ukrainian scholars when writing scientific articles and their attitude to manifestations of academic cheating; to generalize recommendations on the choice of a scientific journal for the publication of scientific research results.

\section{Method}

In May 2018, a survey of Ukrainian scholars on the Ukrainian academic journals' scientific level and their experience in interacting with editiorial boards of academic journals, which are indexed in Web of Science and Scopus, was conducted in the Ukrainian Scientists Worldwide group on Facebook by filling out the Google form. In total, 296 scientists from different fields took part in the survey.

The questionnaire contained 34 questions, 10 of which were open. 14 questions contained ready-made answers, and 10 questions gave scientists the opportunity not only to choose the answer, but also to give their own. This allowed to gather various, often diametrically opposed, scholarly thoughts about why they publish (do not publish) their articles in journals included to Web of Science or Scopus; what the main reviewers' comments on their articles were; for what reason the Ministry of Education and Science 
requires scholars to have articles in academic journals included to international databases; who is financing the publication fee; how important the knowledge of foreign languages for the preparation of scientific papers is; how the authors interact with the editors during the editorial and publishing process; what the main researchers' motivation to write scientific articles is; how scholars evaluate the practice, when people who are not actually co-authors of the articles are added as co-authors by agreement; how the authors refer to plagiarism and on the basis of which criteria researchers select a journal for publication. Quantitative data was analyzed by percentage distribution and Qualitative data by categorization.

\section{Results}

The questionnaire was filled by representatives of 18 specialties: physics and mathematics (48), engineering (42), jurisprudence (36), philology (30), economics (28), biology (22), pedagogy (20), history (14), medicine (14), chemistry (10), social communication (8), philosophy (8), geology (4), public administration (4), agricultural sciences (2), political science (2), physical education and sport (2), psychology (2).

The question of the questionnaire concerned the scientific experience of the respondents. $28 \%$ of them (83) mentioned the experience of scientific activity for more than 20 years, $40 \%$ (119) indicated 11-20 years, $22 \%$ (65) from 6 to 10 years and $10 \%$ (29) up to 5 years.

$33 \%$ of respondents (98) annually publish 1-2 scientific articles, $50 \%$ (147) - from 3 to $5,13 \%(40)$ - from 6 to $10,4 \%(11)$ - more than 10 . As for the number of individual articles that scientists usually print during the year, the responses were distributed as follows: $0-20 \%$ (59), from 1 to $2-50 \%$ (148), from 3 to $5-26 \%$ (77), from 6 to $10-$ $3 \%(9)$, more than $10-1 \%(3)$.

$8 \%$ of respondents (24) have up to 5 articles in professional Ukrainian journals, $12 \%(35)-6-10,23 \%(68)-11-20,32 \%(95)-21-50,25 \%(74)$ - more than 50. At the same time, $32 \%$ of the scientists (95) do not have any publications in academic journals belonging to Web of Science or Scopus, $26 \%$ of the respondents (77) have up to 3 such publications, $10 \%(29)$ - from 4 to $5,10 \%(30)-6-10$, and only $22 \%(65)$ more than 10 .

The question of the benefits of publishing in international peer-reviewed journals was only answered by scientists with such publications. 102 scientists gave detailed answers. In particular, among the advantages they called the following: confirmation of the level of scientific work; visibility in scientific space; world popularization of research; better chances to win a grant / get additional funding from abroad; an opportunity to increase citation; search partners for common scientific topics; the basis for meaningful discussions of the world level; the ability to get comments from reputable reviewers and improve the quality of their research; writing articles because they are interested in science.

Such answers prove the motivation of Ukrainian scientists to work on the scientific result. However, there were also answers that show a desire to ensure first of all quantitative indicators, for example: the ability to defend dissertation work and increase wages; the necessity to participate in the competition for a position and career growth; obtaining a scientific rank; requirements of the administration of a scientific institution or university. 
In eleven comments, it was noted that writing qualitative articles is demotivating by the fact that in Ukrainian realities, the person with several articles in journals, included to international databases, is an idler, and with hundreds of articles in dubious journals, he is a productive author with the best career prospects.

Scientists emphasized that in addition to the bases recommended by the Ministry of Education and Science, there are other authoritative bases, for example for astrophysicists the SAO / NASA Astrophysics Data System (ADS), a Digital Library for researchers in Astronomy and Physics, operated by the Smithsonian Astrophysical Observatory (SAO) under a NASA grant. For biologists with physicians it is MEDILINE or Index Medicus, mathematicians with physics may use ArXiv. For economists there is currently no alternative to RePEc.

The significant answers were given to questions about the blatant disadvantages found in Ukrainian academic journals: plagiarism, lack of novelty, errors in the formulas, incorrect units of measurements, reprints of articles under different headings, fictitious data, the use of the "compilation method", inconsistency of the results, automated translation in English, references to a normative legal act that are no longer valid, etc.

There were also misunderstandings that were encountered by the authors when interacting with reviewers and editors of Ukrainian academic journals. Among them: the reviewer was a scientist, who was fired by the author, contradictory reviews, misunderstanding by the editor of the specifics of terms, sending an article for review to its author, problems with stylistics, the distortion of the title of the article and translating it through Google Translate.

Among the reasons for which the articles were rejected by Ukrainian academic journals, the researchers pointed out that they did not meet the requirements for the structure, a personal conflict with the editor-in-chief, comments on the relevance, inconsistency of materials to the journal. However, $70 \%$ of scholars (207) noted that the Ukrainian professional journals never rejected their articles, but accepted them either at all without comments or with minor comments. Separate respondents indicated that they immediately sent a scanned receipt on payment together with the article.

Instead, journals, that belong to Web of Science Core Collection and / or Scopus, at least one time rejected articles of $86 \%$ of the respondents $(255)$ who sent them to such journals. Among the reasons for this were following: inconsistency in the topic of the journal, the discrepancy with the publishing policy of the journal, the bad English, the lack of experimental data, the citation of publications in journals that are not in the international bases, the lack of comparative analysis, ignoring the requirements to the structure, lack of novelty, insufficient literature review, the lack of an extremely important contribution to the industry, lack of argumentation, methodological flaws, the use of outdated equipment for research, an incorrect form of presentation of results.

Interesting were the answers of scientists who do not have any publication in international peer-reviewed journals (we received responses from 95 respondents). Having the opportunity to choose multiple answer options or to indicate their variant, they mentioned the reasons for the lack of publications: it is expensive (56), "I am overloaded at work and have no time for writing articles for international journals" (48), "I do not 
know English" (31), "I do not know how to write in accordance with the requirements of these journals" (15), "I do not consider these bases as authoritative" (15), "I do not want to wait for a long time" (13), "my topics are not interesting for international journals" (10), "there are no international journals on my subject" (9), "I do not want to support commercial structures" (2).

The next question was intended to reveal what scientists associate with the requirements of the Ministry of Education and Science to scholars to publish in journals belonging to international databases. Of the 262 respondents who answered this question, $51 \%$ (134) believe that this requirement is intended to promote the development of Ukrainian science and to motivate Ukrainian scientific journals to raise the requirements for articles.

However, the rest $49 \%$ of the respondents (128) relate these requirements, first of all, not with the promotion of scientific research results of Ukrainian scholars in the world, but with the intention to reduce the burden on the wage fund; ignoring the economic realities of scientists and educators; bureaucratic imitation of scientific reforms; lack of expert environment in Ukrainian science; the desire to create chaos, in which one can manage in the direction desired by the officials; thoughtless copying of someone else's experience; the efforts of officials to simplify their assessment of the work of scientists; the inability to control the quality of the dissertation; the desire to transfer the promotion of scientific results entirely to the scholars, without providing them with any conditions for this (neither for the continuation of education, nor for the development of scientific projects, nor for trips to the conference abroad), etc.

$36 \%$ of respondents (108) answered "yes" to the question whether they wrote coercive articles, "for formal reporting". In the detailed comments, the respondents had the opportunity to comment on this issue in more details. These comments can be reduced to the following: the requirements of the Ministry of Education and Science on the number of publications for admission to public defense of scientific works forced to work not on the result, but on the number; formal requirements replace the quality and freedom of creative thought, compel to write junk articles; the statistical reporting at the university requires writing as much as possible, and because of the lack of time and material and technical resources, it is impossible to qualitatively prepare the article for high-quality journals; writing only to fulfill an individual plan of work, a contract and not to be fired.

Answering the question about how many invitations to publish for money are usually received by e-mails during the week, $59 \%$ of respondents (175) answered that they received from 1 to 5 proposals, $16 \%$ (47) - from 6 to $10,13 \%$ (39) - more than 10 and only $12 \%$ (35) - none. $72 \%$ of the respondents (213) indicated that their articles were not pre-discussed at the research institution in which they are working before submitting to the scientific journal. Accordingly, only $28 \%$ of the authors (83) pass such a preliminary discussion procedure. Meanwhile, $48 \%$ of respondents (142) always pay for publications, $32 \%$ (95) pay from time to time, and only $20 \%$ (59) are always printed for free. At the same time, $88 \%$ (260) of those publishing for money noted that they finance publications on their own; $5 \%$ (15) use grant funds, sponsors' funds; $6 \%$ (18) are published at the expense of the institution in which they work, and $1 \%$ (3) at 
the expense of co-authors. In our opinion, no article should be published solely at the expense of the author. Because it is a priori clear that this publication is only required by the author for formal reporting.

8 respondents (about $3 \%$ ) admitted that they sometimes falsified the research results, namely, they replaced the statistical data with typical for the region, increased the number of respondents, and overestimated the accuracy of the measurements. Such authors become eager participants in what experts call academic fraud that wastes taxpayer money, chips away at scientific credibility, and muddies important research.

As a result of the survey, it was also found that $54 \%$ of respondents (150) use online translators when writing articles and abstracts in foreign languages, explaining this with insufficient knowledge of a foreign language and the lack of time. 32 respondents (about $9 \%$ ) do not even consider it is necessary to check the quality of such translation, because nobody reads their articles. At the same time, $72 \%$ (213) believe that without the use of scientific sources in the languages of international communication it is impossible to prepare a high-quality article, while $18 \%$ (54) use only Ukrainian and Russian sources. The rest of the respondents (10\% or 29$)$ provided their answers, which are largely due to the branch of science represented by scientists: "It is important to know not only the languages of international communication, for example, the historian must learn, first of all, the language in which the most sources of his problems (for example, the language of the Maya) are left, and not the one that contemporaries speak in different countries", "The main qualities of a researcher, a teacher is the ability to think, to set and solve problems, to be organized, to be able to teach, and all of this primarily in his native language, therefore it is absurd to put his attestation in dependence on knowledge of a foreign language or the presence of foreign-language publications. Such requirements are discriminatory against the Ukrainian language and science. In addition, scientific results in social sciences (history, economics, philology, jurisprudence, etc.) are aimed, first of all, at solving Ukrainian problems and should be formulated mainly in the Ukrainian language and be accessible to the widest range of Ukrainian citizens, regardless of their knowledge of foreign languages", "mathematics has a problem, the scientist solves it. And it is completely indifferent whether he used the achievements of his predecessors and in what language they wrote. His task is to solve a problem not yet solved, but to translate his article a scientific translator is needed."

The questionnaire contained a question about how long scientists usually wait for a positive decision to publish their articles. The results of the survey showed that $14 \%$ (41) expect several years, $18 \%$ (54) - more than 3 months, $32 \%(95)$ - from one month to three, $22 \%$ (65) - from two weeks to a month, $14 \%(41)$ - up to two weeks. At the same time, a direct connection was found out between the term of such expectation and the quality of the scientific activity of the authors. So, most scholars who are published in international peer-reviewed journals have indicated their expectation of more than 3 months and indicated that the reasons for their publication activity are not quantitative indicators, but the confirmation of the level of scientific work; visibility in the scientific space; world popularization of research; search partners for common scientific topics; the ability to get comments from reputable reviewers and improve the quality of their research. 
An interesting were the answers to the question of the interaction of authors with editorial boards of academic journals. Scientists had the opportunity to select several of the proposed and give their own answers. In particular, we received 102 answers: "I only confirm the payment for the publication, I do not take part in the editorial and publishing process," 168 answers "I discuss the correction with the editor," 176 answers "I take note of the comments of the reviewers." An indicator of the dubious quality of certain national scientific journals may also be a generalized version of the answer proposed by 26 authors: "In Ukrainian, I usually only confirm the payment for the publication, in foreign journals I discuss the correction with the editor and take note of the comments of the reviewers."

To write a scientific article (including the selection of materials, experiments, etc.) $8 \%$ of the polled scientists (24 respondents) spend up to one week, $26 \%$ (77) from one week to one month, $34 \%$ (101) from one month to three, $17 \%(50)$ from three months to half a year, $15 \%(44)$ more than half a year.

Regarding the number of scientific papers that the authors are working on when preparing scientific articles (not for review), the study showed the following results: more than $20-55 \%(163)$; 11-20 - $29 \%$ (86); 5-10 - $13 \%(38)$, less than $5-3 \%(9)$.

The questionnaire also made it possible to identify the problematic aspects of the attitude of Ukrainian scholars towards academic dishonesty. So, to the question: "How do you relate to cases when as co-authors of publications are noted people who are not actually co-authors?" 228 (69\%) answered that it was unfair, but the rest (70 or $31 \%$ ) indicated that they are tolerant of this: note their colleagues, who then note them (36); obligate their students and postgraduate students to note them (14); note as coauthors their own students / post-graduate students who only did small technical work for the article to encourage them to further cooperation (6); because of the high cost of publication, they usually consider the possibility of "intellectual slavery" (14).

Meanwhile, 244 respondents (82\%) indicated that they never allowed the use of papers written by other scholars without reference to the author. Others allow such an opportunity as can be seen, for example, from the following answers: "I use the research results of my students and postgraduates" (24); "I take from other articles the methodology of research and only substitute my results" (12); "I compile my article from several foreign-language articles" (9); "I think that it is impossible to invent anything fundamentally new in my field" (5); "I cite the quotation always, but sometimes I can give some ideas as my own" (4).

Answering the question "How do you choose an academic journal for publication?" about $6 \%$ of the respondents (165 people) indicated that they were focusing primarily on topics, the quality of article reviews, the composition of the editorial board, and the reputation of the journals. $59 \%$ of these respondents (98) prefer publications indexed in international databases. The remaining respondents gave their own answers, which testify the low requirements of authors to their own scientific results: "I only print in the journals of the institution in which I work, because it's free"; "I choose journals in which my article can be printed quickly and inexpensively"; "I write the article in English and submit it to a prestigious journal (realizing that the article is not likely to be published 
there). If I get a refusal, it is usually substantiated and with recommendations on how to improve the article. I improve it and send it to the less popular journal, if they refuse, I take note of the comment and lower the level. If I get refusals 6 or 7 times, I send an article to the editorial office, where everything is printed for money"; "Usually publish my articles due to acquaintances"; "I choose journals with low publication fees. All the same article is then available on the Internet, so there is no difference where they are published"; "I do not have meaningful results, therefore, I publish in journals with low requirements."

Then, advice on the preparation of scientific publications was collected from scholars who have articles in international authoritative journals and, accordingly, the experience of communicating with editorial boards of such journals.

In particular, they recommended to pay attention to: the logic of presentation of the material; experimental confirmation of hypotheses ("do not be afraid to visit the Center for Collective Use of Devices of the National Academy of Sciences to conduct several experiments that will strengthen the publication"), substantiation of relevance ("try to impress the editor, remember that every article essentially should begin with words "For the first time in the world"); academic integrity ("do not allow plagiarism and self-plagiarism, do not falsify data"); availability of scientific novelty; substantiation of conclusions; use of modern scientific methods; compliance with the conclusions and purpose of the article; proper design of references and quotations; the practical value of research and the reality of using the results obtained; prospect of continuation of research on the topic; the relevance of the sources used and the design of the bibliography; clear and interesting statement.

Additionally, they advised to write, without adjusting to the political situation and their own likes / dislikes (when, for example, historical or political sciences are concerned); to apply for help to a literary editor ("carefully work not only on practical research, but also on their presentation. The level of knowledge of the Ukrainian language of most authors, unfortunately, is mediocre, although, in the light of current requirements, it is necessary to publish in the publications belonging to Scopus, the knowledge of Ukrainian language is not very important, so let the English speakers now suffer from reading articles from Ukrainian scholars"); to use foreign sources (while taking into account that "foreign sources are not only Russian and Byelorussian"); to present unique results and own opinion, and not only to recapitulate previous studies; to cooperate with foreign colleagues during the research and preparation of articles; do not resort to computer translation and do not submit articles in paper-only editions.

The researchers also gave recommendations on the responsible attitude of authors to the making up the list of quoted sources (References). After all, the References make it possible to evaluate: how deeply the author understands the problem; the ratio of references to domestic and foreign sources; the quality of quoted sources by their type (articles in journals, conference theses, normative documents, textbooks, fiction); the quality of the quoted sources by their name (availability of quotes of articles in dubious journals, in particular those excluded from Scopus or Web of Science; how other similar sources were considered in the context of the topics chosen by the author of the journal; 
the presence of quotes on the results of recent research; percentage of quotes of own previous publications (salami slicing), etc.

Finally, scientists advised editors of Ukrainian academic journals to expand editorial boards, to attract more foreign colleagues to editorial boards and reviewing process. At the same time, members of the editorial board should perform their work, and not just be noted in the list at the beginning of the publication, and they should be elected not only by the criterion of having their high titles and degrees. In addition, scientists recommend checking manuscripts for plagiarism; to cooperate more actively with the authors, to coordinate with them the edits; exclude Russian annotation; to shift the emphasis from the requirements to the form on the requirements to the content; try to go beyond Ukraine with the geography of the authors; move away from multidisciplinarity; switch completely to electronic versions and reduce payment; stop printing pseudoscientific articles for money, select articles for publication by competition; во not print previously published articles.

Finally, motivated authors with publications in international journals of world-class, highlighted the following cases that should alert scientists when choosing a journal to publish research results:

the journal's website or a letter of invitation to the publication states that the journal is the part of the international science-computer bases, and in its databases it either has never been or has already been excluded from them;

lack of information on the websites of the journal and the publisher regarding founders, owners, sponsors;

the journal informs about the deadlines for submitting articles and promises to publish them urgently, although the process of publishing an article in well-known journal with a large reader's audience, which carefully scrutinizes all the materials received, can not be lightning-fast;

the journal constantly and in large numbers publishes the employees of the institution that is the founder of the journal;

well-known specialists in the field do not publish in the journal;

in one issue there are articles from various scientific fields, which are not related to each other;

the journal advertises itself by sending spam;

the editorial board requests a review together with the article;

among the members of the editorial board there are no known researchers in the field from which the article is presented (and even if the members of the editorial board are well-known researchers in their field, it is very good to check if they indicate on their personal web pages that they are members of the editorial board of this journal);

poor grammar, spelling, and punctuation on website and/or in emails;

in the journal it is indicated that the authors are responsible for the accuracy of quotations, surnames, references and other facts given in the text of the submitted articles; given "Requirements to the authors" verbatim (or with very minor changes) copied from sites of other publishers; the publisher unreasonably uses the words «Network», «Center», «Association» or such suspicious phrases as "leading publisher," "best publication", "unique publication" etc. in its name; 
the journal does not have a data retention policy, i.e. there is no guarantee that after the $\log$ is discontinued its content will be retained.

In general, the recommendations for scientists can be reduced to the following requirements: they primarily need to get the original results of the study, choose an authoritative journal, master the process of communicating with the editorial staff and have at least six months of the year in order for the article to be published on time.

\section{Conclusions}

The results of the survey have shown contradictory tendencies of Ukrainian researchers' publication activity. On the one hand, it is a desire to reach the international level, to gain world recognition, an attempt to adhere to high standards, to improve own skills. On the other hand, pursuit of quantitative indicators, low motivation, violations of academic integrity, low level of proficiency in the languages of international scientific communication. In pursuit of quantity there is no place for scientific values, such as novelty, uniqueness, informativeness.

The academic system bears much of the blame for the rise of low-quality articles, demanding publications from teachers without real resources for research and where they may have little time apart from teaching. In addition, there are many basic courses (matanalysis, linear algebra, etc.), as well as purely practical and industrialoriented courses (for example, programming), of which it is generally inappropriate to require publication. Therefore, it is necessary to refuse the evaluation of scientific activity only on a quantitative indicators, because sooner or later such an assessment is limited to the promotion of this indicator. If a scientist has something to say, he will say. And if not, then there are articles that nobody will read in Ukraine or abroad.

The survey has shown a strong need to raise the level of Ukrainian academic journals. Ideally, the editorial team of the journal should keep the evaluation process under control as much as possible and check not only the manuscripts before submitting them to the review, but also prepared reviews to prevent possible billing or misunderstanding of the content of the article by reviewers.

\section{СПИСОК ВИКОРИСТАНИХ ДЖЕРЕЛ}

1. Перелік фахових видань / Міністерство освіти і науки України: офіційний веб-портал. URL: https://mon.gov.ua/ua/nauka/nauka/atestaciya-kadriv-vishoyi-kvalifikaciyi/naukovi-fahovi-vidannya (дата звернення: 12.06.2018).

2. Где не стыдно публиковаться ученому: украинские издания в инфографике. URL: https://innovationhouse.org.ua/statti/gde-ne-stydno-publykovatsya-uchenomu-ukraynskyeyzdanyya-v-ynfografyke/ (дата обращения: 12.06.2018).

3. Abbott J. How to choose where to publish your work. Journal of Orthopaedic \& Sports Physical Therapy. 2017. No. 47 (1). Pp. 6-10.

4. Bergstrom C., Bergstrom T. Can 'author pays' journals compete with 'reader pays'? URL: http://www.nature.com/nature/focus/accessdebate/22.html (retrieved June 12, 2018).

5. Kozak M., Hartley J. Publication fees for open access journals: different disciplines - different methods. Assoc. Inf. Sci. 2013. No. 64 (12). Pp. 2591-2594. 
6. Beall J. Predatory publishers are corrupting open access. Nature. 2012. Vol. 489. P. 179.

7. Beall J. Criteria for determining predatory open-access publishers. URL: https://scholarlyoa. files. wordpress.com/2012/11/criteria-2012-2.pdf (retrieved June 12, 2018).

8. Who publishes in «predatory» journals? / Xia J., Harmon J., Connolly K. et al. Journal of the Association for Information Science and Technology. 2015. No. 66 (7). Pp. 1406-1417 (retrieved June 12, 2018).

9. Kolata G. Many academics are eager to publish in worthless journals. URL: https://files.eric. ed.gov/fulltext/ED579189.pdf (retrieved June 12, 2018).

10. Thrower P. Eight reasons I rejected your article. URL: https://www.elsevier.com/connect/8-reasons-i-rejected-your-article (retrieved June 12, 2018).

11. Про затвердження Порядку формування Переліку наукових фахових видань України: наказ МОН від 15.01.2018 № 32 / Міністерство освіти і науки України: офіційний веб-портал. URL: http://zakon5.rada.gov.ua/laws/show/z0148-18 (дата звернення: 12.06.2018).

\section{REFERENCES}

1. Perelik fakhovykh vydan / Ministerstvo osvity i nauky Ukrainy: ofitsiinyi veb-portal. Retrieved from https://mon.gov.ua/ua/nauka/nauka/atestaciya-kadriv-vishoyi-kvalifikaciyi/naukovi-fahovi-vidannya (data zvernennia: 12.06.2018) (in Ukrainian).

2. Gde ne stydno publikovatsia uchenomu: ukrainskie izdaniia $v$ infografike. Retrieved from https://innovationhouse.org.ua/statti/gde-ne-stydno-publykovatsya-uchenomu-ukraynskyeyzdanyya-v-ynfografyke/ (data obrashcheniia: 12.06.2018) (in Russian).

3. Abbott, J. (2017). How to choose where to publish your work: Journal of Orthopaedic \& Sports Physical Therapy, 47 (1), 6-10 (in English).

4. Bergstrom, C., \& Bergstrom, T. Can 'author pays' journals compete with 'reader pays'? Retrieved from http://www.nature.com/nature/focus/accessdebate/22.html (retrieved June 12, 2018) (in English).

5. Kozak, M., \& Hartley, J. (2013). Publication fees for open access journals: different disciplines - different methods: Assoc. Inf. Sci, 64 (12), 2591-2594 (in English).

6. Beall, J. (2012). Predatory publishers are corrupting open access: Nature, 489, 179 (in English).

7. Beall, J. Criteria for determining predatory open-access publishers. Retrieved from https:// scholarlyoa.files. wordpress.com/2012/11/criteria-2012-2.pdf (retrieved June 12, 2018) (in English).

8. Xia, J., Harmon, J., \& Connolly, K. et al. (2015). Who publishes in «predatory» journals?: Journal of the Association for Information Science and Technology, 66 (7), 1406-1417 (retrieved June 12, 2018) (in English).

9. Kolata, G. Many academics are eager to publish in worthless journals. Retrieved from https://files. eric.ed.gov/fulltext/ED579189.pdf (retrieved June 12, 2018) (in English).

10. Thrower, P. Eight reasons I rejected your article. Retrieved from https://www.elsevier.com/ connect/8-reasons-i-rejected-your-article (retrieved June 12, 2018) (in English).

11. Pro zatverdzhennia Poriadku formuvannia Pereliku naukovykh fakhovykh vydan Ukrainy: nakaz MON vid 15.01.2018 № 32 / Ministerstvo osvity i nauky Ukrainy: ofitsiinyi veb-portal. Retrieved from http://zakon5.rada.gov.ua/laws/show/z0148-18 (data zvernennia: 12.06.2018) (in Ukrainian). 
doi: 10.32403/0554-4866-2018-2-76-128-141

\title{
ОПРИЛЮДНЕННЯ НАУКОВИХ РЕЗУЛЬТАТІВ УКРАЇНСЬКИХ ДОСЛІДНИКІВ У ФАХОВИХ ВИДАННЯХ: ПРОБЛЕМИ І ПЕРСПЕКТИВИ
}

\author{
С. Б. Фіялка
}

\begin{abstract}
Видавничо-поліграфічний інститут Національного технічного університету
України «Київський політехнічний інститут імені Ігоря Сікорського», просп. Перемоги, 37, Київ, 03056, Україна

fiyalka@i.ua
\end{abstract}

Було проведено опитування украӥнських учених щзодо наукового рівня українських фахових видань та досвіду взаємодії авторів з редакціями наукових журналів, які індексуються y Web of Science ma Scopus. Анкету у виглядi google-форми було розміщено в груni Ukrainian Scientists Worldwide на Фейсбуку. У дослідженні взяли участь 296 учених різних галузей. Опитування дозволило зібрати різні, часто діаметрально протилежні, думки про те, чому науковиі публікують (не публікують) свої статті в журналах, включених до Web of Science або Scopus; які відгуки рецензентів вони отримували на свої статті; з якої причини, на їхню думку, Міністерство освіти $і$ науки вимагає, щоб науковці публікувалися в журналах, включених до міжнародних наукометричних баз; хто фінансує оплату публікацій; наскільки важливе знання іноземних мов для підготовки наукових пращь; як автори взаємодіють з редакторами під час редакційно-видавничого прочесу; якою є мотивачія науковців до написання наукових статей; як учені очінюють практику, коли людей, які насправді не є співавторали статей, за домовленістю вписують як співавторів публікацій; як автори ставляться до плагіату та на підставі яких критерії дослідники вибирають журнал для публікації.

Результати опитування показали суперечливі тенденції в ставленні украӥнських дослідників до результатів власної праці. 3 одного боку, иче прагнення досягти міжнародного рівня, отримати світове визнання, спроба дотримуватися високих стандартів, самовдосконалюватися. 3 другого боку, прагнення лише до кількісних показників, низька мотивачія, порушення академічної доброчесності, недостатній рівень володіння мовами міжнародного наукового спілкування. У гонитві за кількісними показниками публікаційної активності не залишається місия для наукових иунностей, таких як новизна, унікальність, інформативність.

Ключові слова: науковий журнал, академічна доброчесність, плагіат, рецензія, рецензований журнал, редагування, редколегія. 